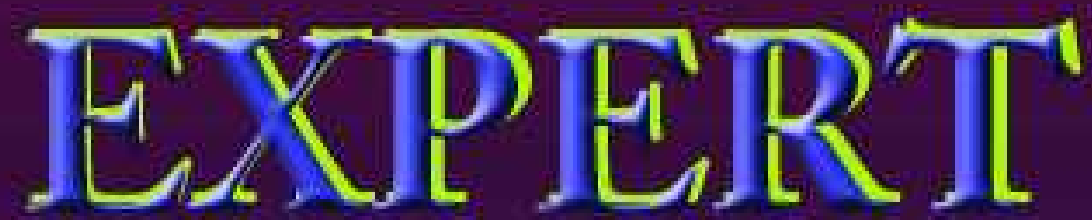

Jurnal Sistem Informasi

PENGEMBANGAN SISTEM APLIKASI LOKASI RUMAH KOST KABUPATEN PRINGSEWU BERBASIS WEB MOBILE

Elisabet Yunaeti Anggareni, Elieser Rudi HCN, Mad Muhaidi

KONSULTASI AKADEMIK BERBASIS ONLINE PROCESSING

Fenty Ariani, Robby Yuli Endra

PERENCANAAN ARSITEKTUR SISTEM INFORMASI MENGGUNAKAN MODEL ENTERPRISE ARCHITECTURE PLANNING (EAP)

di DIREKTORAT RESERSE KRIMINAL UMUM POLDA LAMPUNG

Hilda Dwi Yunita

DECISION SUPPORT SYSTEMMENGGUNAKAN METODE SAW DALAM MENENTUKAN KINERJA APARATUR PEMERINTAH KECAMATAN

M. Islam Mahdi, Rinawati, Tri Susilowati, Zul Kirom

PEMILIHAN CAFE TERBAIK MENGGUNAKAN METODE ANALYTICAL HIERARCHY PROCESS ( AHP)

Sti Ipnuwati, Khusnul Khotimah, Keni Puspita Sari

PEMETAAN COBIT 4.1 UNTUK PENILAIAN KEMATANGAN TATA KELOLA TI Yuthsi Aprilinda, Ayu Kartika Puspa

ISSN : 2088-5555 


\section{Expert}

Jurnal Manajemen Sistem Informasi dan Teknologi

Volume 08, Nomor 01, Juni 2018

\begin{tabular}{|l|l|}
\hline Judul & Hal \\
\hline $\begin{array}{l}\text { PENGEMBANGAN SISTEM APLIKASI LOKASI RUMAH } \\
\text { KOST KABUPATEN PRINGSEWU BERBASIS WEB MOBILE }\end{array}$ & $1-4$ \\
\hline $\begin{array}{l}\text { KONSULTASI AKADEMIK BERBASIS ONLINE } \\
\text { PROCESSING }\end{array}$ & $5-13$ \\
\hline $\begin{array}{l}\text { PERENCANAAN ARSITEKTUR SISTEM INFORMASI } \\
\text { MENGGUNAKAN MODEL ENTERPRISE ARCHITECTURE } \\
\text { PLANNING (EAP) di DIREKTORAT RESERSE KRIMINAL }\end{array}$ & $13-21$ \\
UMUM POLDA LAMPUNG & \\
\hline $\begin{array}{l}\text { DECISION SUPPORT SYSTEMMENGGUNAKAN METODE } \\
\text { SAW DALAM MENENTUKAN KINERJA APARATUR }\end{array}$ & $22-28$ \\
PEMERINTAH KECAMATAN & $29-38$ \\
\hline $\begin{array}{l}\text { PEMILIHAN CAFE TERBAIK MENGGUNAKAN METODE } \\
\text { ANALYTICAL HIERARCHY PROCESS AHP) }\end{array}$ & $39-48$ \\
\hline $\begin{array}{l}\text { PEMETAAN COBIT 4.1 UNTUK PENILAIAN } \\
\text { KEMATANGAN TATA KELOLA TI }\end{array}$ & \\
\hline
\end{tabular}

Fakultas Ilmu Komputer

Universitas Bandar Lampung

\begin{tabular}{|l|l|l|l|l|}
\hline JMSIT & Volume 08 & Nomor 01 & Lampung, Juni 2018 & ISSN 2088-5555 \\
\hline
\end{tabular}




\section{TIM PENYUNTING}

\section{Penanggung Jawab}

Ahmad Cucus, S.Kom., M.Kom.

Ketua Tim Redaksi:

Taqwan Thamrin, ST, M.Sc.

Penyunting Ahli (Mitra Bestari):

Mustofa Usman, Ph.D (Universitas Lampung)

Dra. Wamiliana, MA., Ph.D (Universitas Lampung)

Iing Lukman, M.Sc., Ph. D (Universitas Malahayati)

\section{Penyunting:}

Handri Santoso, M.Eng., Dr. Eng

Fenty Ariani, S.Kom, M.Kom

Robby Yuli Endra, S.Kom.,M.Kom

Ayu Kartika Puspa, S.Kom, M.TI

Erlangga, S.Kom, M.Kom

Pelaksana Teknis:

Wingky Kusuma, S.Kom

\section{Alamat Penerbit/Redaksi:}

Pusat Studi Teknologi Informasi

Fakultas Ilmu Komputer

Universitas Bandar Lampung

Gedung M Lt.2

Jl. ZA Pagar Alam No.89, Gedong Meneng, Rajabasa

Bandar Lampung

Email: jurnalfik@ubl.ac.id 


\title{
PERENCANAAN ARSITEKTUR SISTEM INFORMASI MENGGUNAKAN MODEL ENTERPRISE ARCHITECTURE PLANNING (EAP) di DIREKTORAT RESERSE KRIMINAL UMUM POLDA LAMPUNG
}

\author{
Hilda Dwi Yunita \\ Program Studi Sistem Informasi \\ STMIK Mitra Lampung \\ Jl. Z.A Pagar Alam No.7 Gedongmeneng Bandar Lampung - Indonesia \\ Telp. (0721) 701418 Fax.(0721) 788960 \\ hildadwiyunita@umitra.ac.id
}

\begin{abstract}
Lampung Police is primary implementer unit under Republic of Indonesian Police. It has some work units, one of them is General Crime Reserse Directory (Direskrimum) as unit of General Crime. Ditreskrimum doesn't has the exist planning for its development of information system, so its development just based on the current necessity that uncertain and it doesn't reach the optimal benefit. Based on that case, Direskrimum needs a blueprint about organization information like enterprise architecture. Enterprise Architecture Planning (EAP) is a method or concept to build an information architecture. EAP explains about datas architecture, application and technology for support the organizational business. Enterprise architecture form reffers to business function used to business with Police Report Revenue, Research and Investigation.
\end{abstract}

Keywords: Enterprise Architecture Planning, Datas Architecture, Application Architecture, Technology Architecture

\section{PENDAHULUAN}

\subsection{Latar Belakang Masalah}

Polda Lampung merupakan satuan pelaksana utama kewilayahan yang berada dibawah Polri. Polda bertugas menyelenggarakan tugas Polri pada tingkat kewilayahan. Polda adalah sebuah instansi pemerintah yang bergerak di bidang keamanan dan ketertiban didalam masayarakat. Polda dipimpin oleh Kepala Kepolisian Daerah (Kapolda). Polda memiliki beberapa satuan kerja, salah satunya adalah Direktorat Reserse Kriminal Umum (Ditreskrimum) yang merupakan salah satu Satker untuk menangani tindak pidana kriminal umum.

Di dalam menjalankan tugasnya sebagai pelayanan masyarakat, Direktorat Reserse Kriminal Umum Polda Lampung dituntut untuk memperbaiki dan mengembangkan sistem informasi yang ada. Pembangunan dan pengembangan sistem informasi ini harus selaras dan sesuai dengan arah strategi organisasi (enterprise). Permasalahan yang dihadapi di Direktorat Reserse Kriminal Umum Polda Lampung dalam pengembangan sistem informasi yaitu tidak mempunyai rencana yang jelas dalam pengembangan sistem informasi, sehingga pembangunan hanya berdasarkan kepada kebutuhan saat itu yang belum tentu tepat atau memiliki nilai manfaat yang optimal. Oleh sebab itu diperlukan suatu bentuk blueprint mengenai informasi organisasi berupa arsitektur enterprise yang dapat digunakan untuk mendukung strategi-strategi kebijakan yang diambil pihak manajemen dalam melakukan langkah pengembangan sistem yang terorganisasi dan terintegrasi.

\subsection{Identifikasi Masalah}

Permasalahan yang dihadapi di Direktorat Reserse Kriminal Umum Polda Lampung dalam pengembangan sistem informasi yaitu tidak mempunyai rencana yang jelas dalam pengembangan sistem informasi, sehingga pembangunan hanya berdasarkan kepada kebutuhan saat itu yang belum tentu tepat atau memiliki nilai manfaat yang optimal.

\subsection{Rumusan Masalah}

Berdasarkan dari identifikasi masalah maka dapat diketahui permasalahan yang ada, yaitu : Bagaimana membangun atau merancang model arsitektur sistem informasi pada Polda Lampung yang dapat dipahami oleh setiap entitas yang terlibat dalam bisnis atau organisasi, khususnya pada Direktorat Reserse Kriminal Umum. 


\subsection{Tujuan Penelitian}

Tujuan dari perencanaan arsitektur informasi ini adalah membangun atau merancang blueprint architecture enterprise (data, aplikasi dan teknologi) yang selaras dan sesuai dengan arah strategi organisasi dan yang dapat digunakan sebagai bahan usulan untuk mengembangkan sistem informasinya. Blueprint tersebut dibangun dengan menggunakan metode EAP.

\subsection{Kegunaan atau Manfaat Penelitian}

Adapun kegunaan atau manfaat yang diharapkan antara lain :

1) Untuk membantu Polda Lampung dalam pengembangan blueprint dan mendukung arah strategi perencanaan dan pengembangan organisasi khususnya pada Direktorat Reserse Kriminal Umum.

2) Diharapkan dengan adanya blueprint tersebut, Direktorat Reserse Kriminal Umum Polda Lampung dapat mengatasi permasalahan yang ada dan memudahkan dalam pembangunan atau pengembangan sistem informasi sesuai dengan kebutuhan dan proses bisnis yang ada.

\section{LANDASAN TEORI}

\subsection{Penelitian Terkait}

Pada penelitian (Utomo, 2014) berjudul Pemodelan Arsitektur Enterprise Sistem Informasi Akademik Pada Perguruan Tinggi Menggunakan Enterprise Architecture Planning. Penelitian ini membahas tentang penggunaan konsep EAP untuk membuat blueprint sistem informasi akademik di Perguruan Tinggi yang berisikan berbagai arsitektur diantaranya arsitektur data, aplikasi dan teknologi.

Penelitian yang berjudul Pemodelan Arsitektur Enterprise Untuk Strategi Pengelolaan Aplikasi Bidang Tanggap Darurat Bencana (Khairina et al., 2012). Penelitian ini membahas tentang pemodelan arsitektur enterprise yang menghasilkan arsitektur data, aplikasi dan teknologi serta arah implementasi bagi enterprise di bidang tanggap darurat bencana dalam pemanfaatan sistem informasi.

Penelitian lain yang berjudul Pemodelan Arsitektur Enterprise Menggunakan Enterprise Architecture Planning Untuk Pelayanan Kepada Pelanggan Di PT. Indosat Tbk. Sales Area Kendari (Mentang, 2011). Penelitian ini menjelaskan bahwa PT. Satellite Corporation TBK adalah sebuah penyelenggara jasa telekomunikasi internasional di Indonesia. Hasil dari pemodelan EAP memberikan dokumentasi dan rujukan kepada Indosat Sales Area Kendari dengan rekapitulasi yang terdiri dari model bisnis fungsional, katalog sumber daya informasi (IRC), arsitektur data, arsitektur aplikasi, dan arsitektur teknologi.

Penelitian selanjutnya yang berjudul Perencanaan Arsitektur Enterprise Sistem Informasi Pada Kantor Otoritas Pelabuhan Penyeberangan (KOPP) Ditjen Perhubungan Darat (Afrizal, 2013). Penelitian ini menghasilkan cetak biru dari EAP yang merupakan model tingkat tinggi yang harus dijabarkan kedalam tingkat rendah dalam implementasi sistem informasi.

Dari beberapa hasil penelitian terkait diatas, maka dapat disimpulkan bahwa EAP dapat menghasilkan cetak biru atau blue print tentang arsitektur data, aplikasi dan teknologi suatu organisasi atau perusahaan. Maka dibuatlah suatu penelitian tentang EAP pada Ditreskrimum Polda Lampung.

\subsection{Sistem Informasi}

Sistem Informasi adalah suatu sistem didalam suatu organisasi yang mempertemukan kebutuhan pengolahan transaksi harian, mendukung operasi, bersifat manajerial dan kegiatan startegi dari suatu organisasi dan menyediakan pihak luar tertentu dengan laporan-laporan yang diperlukan (Tahriludin, 2012).

(Sutabri, 2003) Sistem Informasi adalah suatu sistem didalam suatu organisasi yang mempertemukan kebutuhan pengolahan transaksi harian yang mendukung fungsi operasi organisasi yang bersifat manajerial dengan kegiatan strategi dari suatu organisasi untuk dapat menyediakan kepada pihak luar tertentu dengan laporan-laporan yang diperlukan.

(Kristanto, 2008) Sistem Informasi dapat didefenisikan sebagai berikut :

1. Suatu sistem yang dibuat oleh manusia yang terdiri dari komponen-komponen dalam organisasi untuk mencapai suatu tujuan yaitu menyajikan informasi.

2. Sekumpulan prosedur organisasi yang ada pada saat dilaksanakan akan memberikan informasi bagi pengambil keputusan dan atau untuk mengendalikan organisasi. 
3. Suatu sistem didalam organisasi yang mempertemukan kebutuhan pengolahan transaksi, mendukung operasi, bersifat manajerial dan kegiatan strategi dari suatu organisasi dan menyediakan pihak luar tertentu dengan laporan-laporan yang diperlukan.

\subsection{Enterprise Architecture}

Enterprise Architecture merupakan suatu pendekatan logis yang komprehensif dan holistik untuk merancang dan mengimplementasikan sistem dan komponen sistem secara bersama-sama yang meliputi suatu infrastruktur manajemen informasi/teknologi.

Enterprise Architecture dapat dijadikan acuan atau pedoman pada saat akan mengembangkan sistem informasi dan komunikasi. Karena Enterprise Architecture merupakan suatu cetak biru (Khairina, Mustafid, \& Noranita, 2012).

\subsection{Enterprise Architecture Planning (EAP)}

Enterprise Architecture Planning (EAP) merupakan suatu pendekatan yang dibuat oleh Steven H. Spewak untuk membangun arsitektur enterprise dengan berdasarkan dorongan data dan dorongan bisnis. Enterprise Architecture Planning adalah proses pendefinisian arsitektur dalam penggunaan informasi untuk mendukung bisnis dan rencana untuk mengimplementasikan arsitektur tersebut (Spewak, 1992).

Menurut Steven H. Spewak, EAP dinyatakan bahwa pemakaian istilah arsitektur terdiri dari arsitektur data, arsitektur aplikasi dan arsitektur teknologi. Arsitektur disini sebagaimana layaknya cetak biru, penggambaran, atau model. Pada dasarnya EAP bukan merancang bisnis dan arsitekturnya, tetapi mendefiniskan kebutuhan bisnis dan arsitekturnya. Semua arsitektur tersebut dibutuhkan untuk mendukung bisnis yang diselenggarakan oleh enterprise.

Enterprise Architecture Planning (EAP), memiliki 7 (tujuh) komponen utama yang menunjukkan tahapan untuk menentukan dan merencanakan implementasi arsitektur sistem informasi. Tujuh komponen utama ini dikelompokkan menjadi 4 (empat) lapisan (Spewak, 1992). Hal ini dapat dilihat pada gambar 1 :

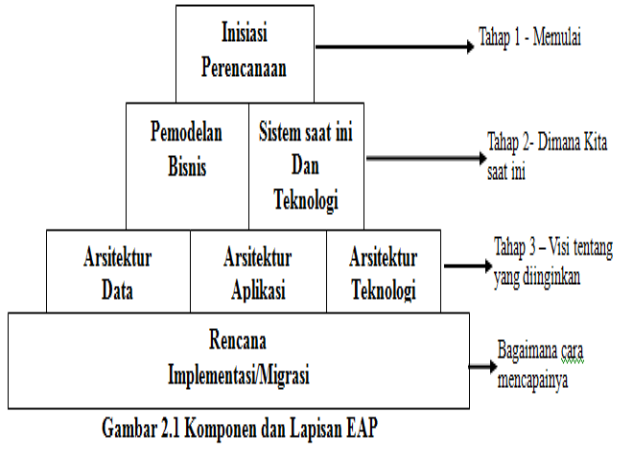

2.5 Model Rantai Nilai (Value Chain)

Model rantai nilai (value chain) pertama kali diusulkan oleh (Porter, 1985), yang terdiri dari satu rangkaian aktivitas yang menciptakan dan membangun suatu nilai yang dapat menghasilkan margin nilai tambah bagi organisasi.

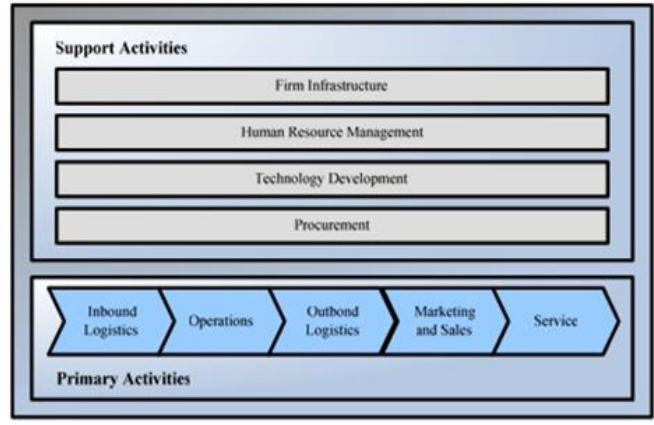

Gambar 2. Model Rantai Nilai (Value Chain)

\subsection{Information Resource Catalog (IRC)}

IRC digunakan untuk mendokumentasikan dan mendefinisikan semua landasan sistem dan teknologi yang sedang digunakan dalam enterprise. IRC tidak menjabarkan setiap sistem secara terperinci, melainkan ringkasannya saja. IRC juga bukan kamus data ataupun inventori peralatan komputasi.

\subsection{Matriks Proses Vs. Entitas Data}

Hubungan antara area fungsi dan entitas data adalah dalam hal pembuatan, pengolahan, dan penggunaan data untuk keperluan pemenuhan tujuan fungsi bisnis. Hubungan ini didefinisikan melalui matriks proses terhadap entitasdata, dimana masingmasing sel dalam matriks diisi dengan huruf : "C" (create), "U" (update), dan "R" (reference). Penanda tersebut bermakna proses yang bersangkutan membuat (create), melakukan (upadate), dan menggunakan (reference) entitas data terkait. 
Proses yang melakukan "C" mengimplikasikan "U" dan "R", sedangkan proses yang melakukan "U" mengimplikasikan "R” (Mentang, 2011).

\section{METODOLOGI PENELITIAN}

\subsection{Bahan Penelitian}

Bahan yang dibutuhkan dalam penelitian adalah berupa data primer dan data sekunder. Data primer didapat dengan melakukan wawancara terhadap pihak terkait dengan penelitian sedangkan data sekunder didapat dengan pengumpulan naskahnaskah, dokumentasi atau laporan dari sumber data. Adapun data yang dibutuhkan dalam penelitian ini dapat dilihat pada Tabel 1 .

Tabel 1. Data Yang Dibutuhkan Dalam Penelitian

\begin{tabular}{|c|c|c|}
\hline Tahap Kegiatan & Aktifitas Permasalahan & Data Yang Dibutuhkan \\
\hline Permulaan & Inisialisasi Perencanaan & $\begin{array}{l}\text { Kumpulan aturan visi, misi } \\
\text { dan segala yang meniadi } \\
\text { rujukan di Direskrimum } \\
\text { terkait pengembangan } \\
\text { sistem informasi }\end{array}$ \\
\hline & Pemodelan Proses Bisnis & $\begin{array}{l}\text { Bagan organisasi serta data } \\
\text { area bisnis/business process }\end{array}$ \\
\hline $\begin{array}{l}\text { Tinjauan Kondisi } \\
\text { Enterprise Saat ini }\end{array}$ & $\begin{array}{l}\text { Sistem dan teknologi saat } \\
\text { ini }\end{array}$ & $\begin{array}{l}\text { Daftar sistem aplikasi serta } \\
\text { platform teknologi yang } \\
\text { digunakan untuk mendukung } \\
\text { bisnis enterprise saat ini }\end{array}$ \\
\hline \multirow{3}{*}{ Perancangan Arsitektur } & Arsitektur data & $\begin{array}{l}\text { Daftar entitas data utama yang } \\
\text { digunakan }\end{array}$ \\
\hline & Arsitektur aplikasi & Daftar aplikasi yang digunakan \\
\hline & Arsitektur teknologi & $\begin{array}{l}\text { Daftar teknologi yang } \\
\text { digunakan }\end{array}$ \\
\hline
\end{tabular}

\subsection{Alat Penelitian}

Alat yang dibutuhkan dalam penelitian terdiri dari alat bantu analisis dan alat bantu deskripsi, dimana :

1. Alat bantu analisis adalah alat yang digunakan dan dibutuhkan untuk membantu melakukan analisis selama penelitian yaitu berupa metodologi Enterprise Architecture Planning (EAP)

2.Alat bantu deskripsi adalah alat bantu yang digunakan dan dibutuhkan untuk tampilan masukan dan keluaran yaitu berupa model, narasi, tabel, bagan hirarki, dan matriks serta perangkat komputer.

\subsection{Roadmap Enterprise Architecture Planning}

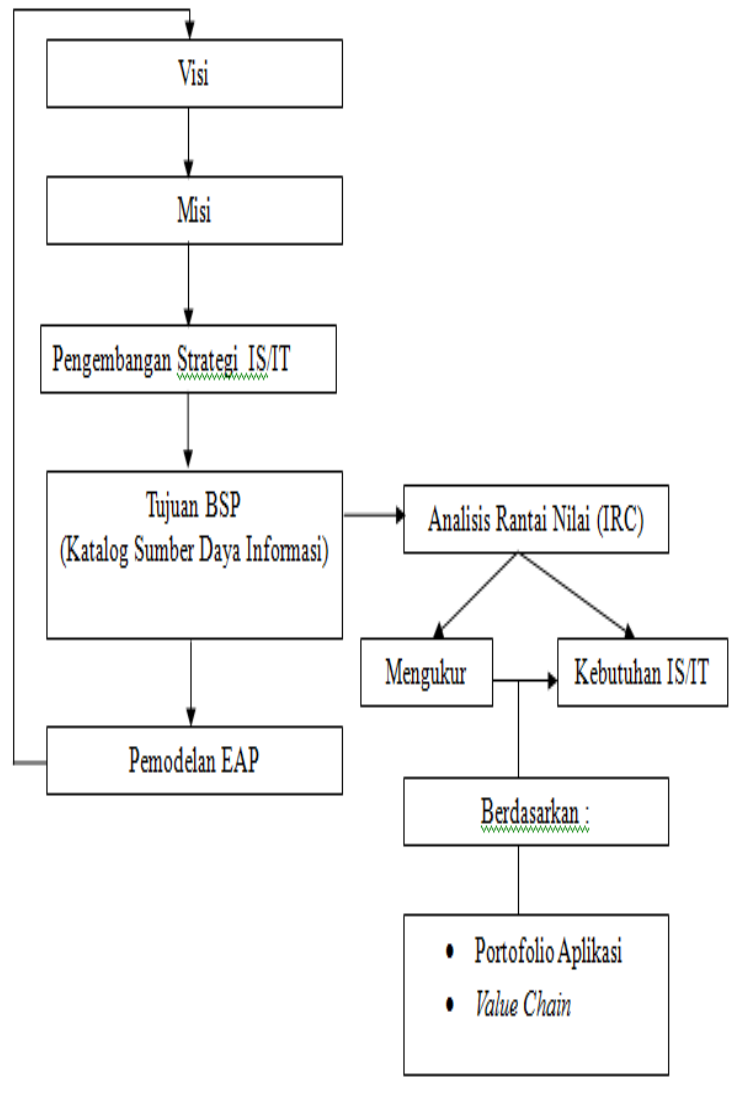

Gambar 3. Roadmap Enterprise Architecture Planning

\subsection{Metode Penelitian}

\section{Studi Kelayakan/Kepustakaan (Library Research)}

Pada tahap ini dilakukan dengan cara mencari literatur terhadap bahan-bahan materi yang dibutuhkan yang berhubungan dengan topik yang diambil sebagai dasar pembahasan, serta untuk memperoleh landasan-landasan teori untuk menggali lebih jauh lagi tentang metodologi dari EAP dalam pengembangan sistem informasi.

\section{Pengumpulan Data}

Pada tahap ini dilakukan dengan dua cara, yaitu :

1.Pengamatan langsung ke lokasi penelitian (observasi) guna melihat secara langsung hal-hal atau data-data yang berkaitan dengan materi yang dibutuhkan dalam penyusunan penelitian seperti mempelajari dokumentasi, tujuan dan struktur organisasi, business process, dan kebijakan teknologi informasi yang ada.

2.Wawancara atau Tanya jawab kepada Kabag Wassidik di Ditreskrimum yang berhubungan dengan TI atau dengan pihak-pihak yang berkaitan dengan penelitian. 


\subsection{Value Chain Ditreskrimum}

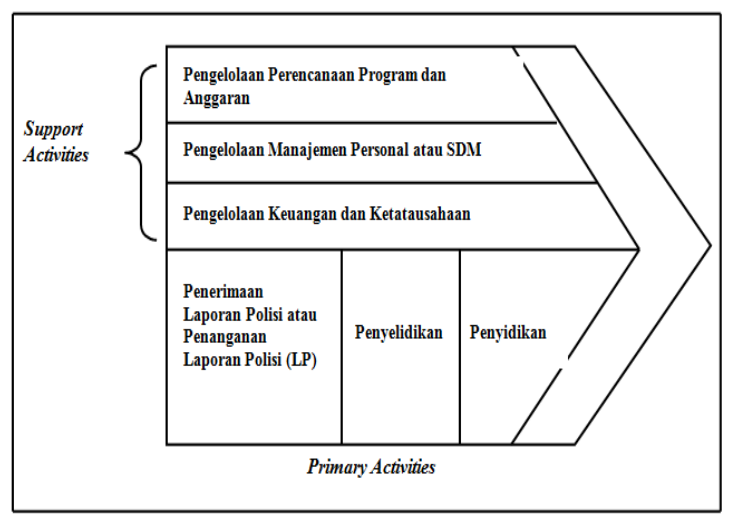

Gambar 4. Value Chain Ditreskrimum

\section{HASIL DAN PEMBAHASAN}

\subsection{Identifikasi Masalah Enterprise}

Dari hasil pengamatan dan tinjauan, dikemukakan beberapa permasalahan berkaitan dengan business process dan dukungan sistem informasi dan teknologi informasi sebagai berikut :

1.Business process belum terdokumentasi dengan baik.

2.Sumber daya manusia/tenaga IT Support yang masih terbatas.

3.Penggunaan sisten informasi dan teknologi informasi belum dimanfaatkan secara optimal. Masih adanya fungsi bisnis yang belum mendapat dukungan sistem berbasis teknologi serta pemanfaatan teknologi informasi dalam mendukung fungsi bisnis belum dilakukan secara maksimal.

4.Infrastruktur pendukung untuk mendukung sistem informasi dan teknologi informasi yang masih terbatas.

5.Belum maksimalnya dokumentasi/ modul perencanaan pengembangan sistem informasi yang dapat memberikan arah untuk pengembangan sistem informasi ke depan/lebih baik yang menunjang business process.

\subsection{Pemodelan Arsitektur Enterprise}

\section{Arsitektur Data}

Arsitektur data harus dapat mengimplementasi data yang mendukung fungsi-fungsi bisnis seperti yang terdefinisi dalam model bisnis. Pada pemodelan bisnis dengan menggunakan rantai nilai dapat dilihat bahwa fungsi-fungsi bisnis utama Direktorat Reserse Kriminal Umum Polda Lampung adalah penerimaan laporan Polisi atau penanganan laporan Polisi (LP), Penyelidikan, dan penyidikan. Oleh karena itu entitas data yang terdefinisi seharusnya dapat menunjukkan dukungannya terhadap fungsi-fungsi bisnis utama ini. Selain fungsi-fungsi bisnis utama pemodelan bisnis juga menunjukkan adanya kegiatan-kegiatan pendukung yaitu pengelolaan perencanaan program dan anggaran, pengelolaan manajemen personel atau SDM, dan pengelolaan keuangan dan ketatausahaan.

Arsitektur data mengidentifikasi dan mendefinisikan data yang mendukung fungsi-fungsi bisnis yang terdefinisi dalam model bisnis arsitektur data berisi entitas-entitas data dimasa masing-masing entitas tersebut memiliki atribut dan membentuk relasi dengan entitas data lain.

Langkah-langkah dalam membentuk arsitektur data adalah :

1. Mendaftar kandidat entitas-entitas data.

2. Merelasikan entitas dengan fungsi bisnis.

3. Mendefinisikan entitas, atribut dan relasi.

\section{Kandidat Entitas Data}

Tujuan dari tahapan ini adalah untuk mendefinisikan semua entitas-entitas data potensial yang diperlukan untuk mendukung bisnis. Dikarenakan entitas-entitas data diperlukan untuk mendukung bisnis, maka penentuannya dapat didasarkan pada fungsi-fungsi bisnis yang telah dirumuskan yang berfokus pada kegiatan utama dalam value chain Direktorat Reserse Kriminal Umum Polda Lampung terdapat beberapa entitas bisnis yang akan diidentifikasi yaitu :

1.Entitas Penerimaan Laporan Polisi atau Penanganan Laporan Polisi (LP)

2.Entitas Penyelidikan

3.Entitas Penyidikan

Tabel 2. Kandidat Entitas Data

\begin{tabular}{|l|l|}
\hline \multicolumn{1}{|c|}{ Entitas Bisnis } & \multicolumn{1}{c|}{ Entitas Data } \\
\hline Entitas Penerimaan Laporan Polisi & 1. Entitas Agenda Masuk \\
atau Penanganan Laporan Polisi & 2. Entitas Laporan Polisi (LP) \\
(LP) & 3. Entitas Register \\
& 4. Entitas Laporan Perkembangan \\
\hline Entitas Penyelidikan & 1. Entitas hasil TKP \\
& 2. Entitas hasil pengamatan \\
& 3. Entitas hasil wawancara \\
& 4. Entitas dokumen \\
\hline Entitas Penyidikan & 1. Entitas hasil penyelidikan \\
& 2. Entitas SPDP \\
& 3. Entitas berkas perkara \\
\hline
\end{tabular}




\section{Arsitektur Aplikasi}

Tahapan yang dilakukan untuk membuat arsitektur aplikasi mempunyai tujuan untuk mendefinisikan aplikasi-aplikasi yang diperlukan untuk mengelola data dan mendukung fungsi-fungsi bisnis bagi enterprise. Arsitektur aplikasi merupakan definisi mengenai apa yang harus dilakukan aplikasi untuk mengelola data dan menyediakan informasi bagi pelaksana-pelaksana fungsi bisnis.

Tahapan untuk menghasilkan arsitektur aplikasi adalah :

1.Mendaftar kandidat aplikasi

2.Mendefinisikan aplikasi

3.Merelasikan aplikasi dengan entitas

4.Merelasikan aplikasi dengan fungsi

\section{Kandidat Aplikasi}

Tujuan dari tahapan ini adalah untuk mengidentifikasi aplikasi-aplikasi yang diperlukan untuk mengelola data dan mendukung bisnis.

Pendefinisian kandidat aplikasi berdasarkan fungsi bisnis didukung maupun tidak didukung oleh aplikasi, maka dapat ditentukan daftar kandidat aplikasi yang diperlukan untuk mendukung proses bisnis utama dalam pelayanan informasi. Daftar kandidat aplikasi terdapat pada tabel 3.

\section{Tabel 3. Daftar Kandidat Aplikasi}

\begin{tabular}{|c|c|c|c|}
\hline No. & Kelompok Aplikasi & No. & Kandidat Aplikasi \\
\hline \multirow{4}{*}{1.} & \multirow{4}{*}{ 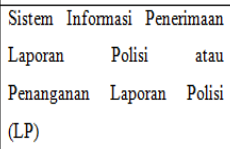 } & 1.1 & Pengelolaan Agenda Masuk \\
\hline & & 1.2 & Pengelolaan Laporan Polisi \\
\hline & & 1.3 & Pengelolaan Register \\
\hline & & 1.4 & Pengelolaan Laporan Perkembangan \\
\hline \multirow{4}{*}{2.} & \multirow{4}{*}{ Sistem Informasi Penyelidikan } & 2.1 & Pengelolaan Hasil TKP \\
\hline & & 2.2 & Pengelolaan Hasil Pengamatan \\
\hline & & 2.3 & Pengelolaan Hasil Wawancara \\
\hline & & 2.4 & Pengelolaan Dokumen \\
\hline \multirow{3}{*}{3.} & \multirow{3}{*}{ Sistem Informasi Penyidikan } & 3.1 & Pengelolaan Hasil Penyelidikan \\
\hline & & 3.2 & Pengelolaan SPDP \\
\hline & & 3.3 & Pengelolaan Berkas Perkara \\
\hline
\end{tabular}

\section{Definisi Aplikasi}

Tujuan dari tahapan ini adalah untuk menyediakan definisi standar mengenai masingmasing aplikasi. Definisi mengenai kelompok aplikasi dijelaskan pada tabel 4.

Tabel 4. Deskripsi Aplikasi

\begin{tabular}{|l|l|}
\hline Kelompok Aplikasi I Sistem Informasi Penerimaan Laporan Polisi (LP) \\
\hline No. & 1 \\
\hline Nama & Sistem Informasi Penerimaan Laporan Polisi (LP) \\
\hline Deskripsi & $\begin{array}{l}\text { Aplikasi ini untuk mengelola data agenda masuk, laporan Polisi, register dan laporan } \\
\text { perkembangan. }\end{array}$ \\
\hline Kelompok Aplikasi 2 Sistem Informasi Penyelidikan \\
\hline No. & 2 \\
\hline Nama. & Sistem Informasi Penyelidikan \\
\hline Deskrpsi & $\begin{array}{l}\text { Aplikasi ini untuk mengelola data hasil TKP, hasil pengamatan, hasil wawancara, dan } \\
\text { dokumen. }\end{array}$ \\
\hline Kelompok Aplikasi 3 Sistem Informasi Penyidikan \\
\hline No. & 3 \\
\hline Nama & Sistem Informasi Penyidikan \\
\hline Deskripsi & Aplikasi ini untuk mengelola data hasil penyelidikan, SPDP, dan berkas perkara. \\
\hline
\end{tabular}

\section{Arsitektur Teknologi}

Penggunaan sumber daya yang sama oleh sejumlah aplikasi untuk mendukung beberapa fungsi yang sama menunjukkan bahwa sebenarnya aplikasi tersebut seharusnya dapat saling berbagi fungsionalitas dan informasi secara bersama, namun dikarenakan aplikasi-aplikasi tersebut memiliki platform berbeda maka tidak dapat berkomunikasi satu sama lain.

Oleh karena itu kebutuhan teknologi bagi Ditreskrimum Polda Lampung adalah teknologi yang mampu mengoptimasi penggunaan teknologi jaringan sehingga antara aplikasi bukan hanya dapat berbagi jalur komunikasi namun dapat saling berbagi data dan informasi.

Arsitektur teknologi dibuat untuk mendefinisikan teknologi yang diperlukan untuk dapat menyediakan lingkungan bagi aplikasi dalam mengelola data. Sama halnya dengan arsitektur data dan aplikasi, arsitektur teknologi juga merupakan model konseptual yang mendefinisikan platform. Tahapan-tahapan dalam pembuatan arsitektur teknologi adalah :

1.Mengidentifikasi prinsip dan platform teknologi 2. Mendefinisikan platform

3.Merelasikan platform teknologi dan aplikasi.

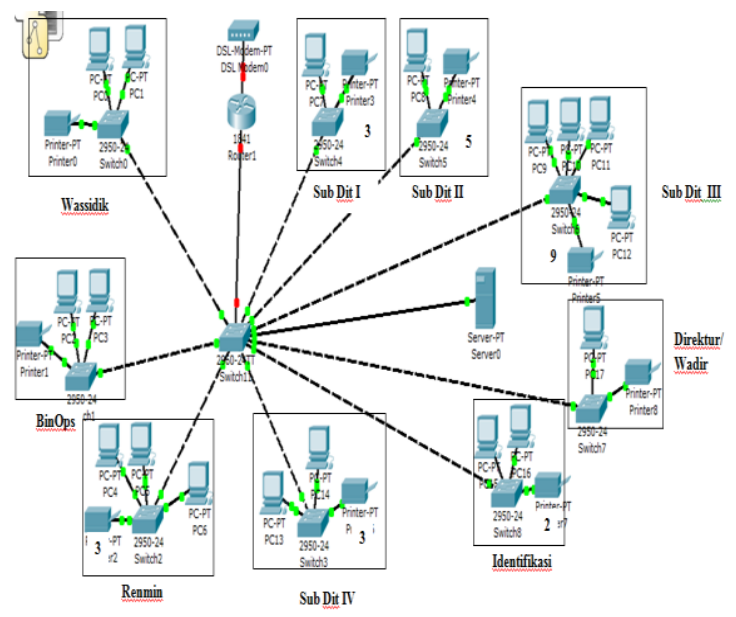

Gambar 5 Arsitektur Teknologi 


\subsection{Rencana Impleentasi}

Rencana penerapan merupakan rencana yang dipersiapkan untuk mengimplementasikan enterprise architecture. Rencana enterprise architecture yang akan diimplementasikan didasarkan pada model bisnis, katalog sumber daya informasi dan arsitekturarsitektur yang telah didefinisikan sebelumnya.

Langkah awal yang dilakukan adalah menyusun urutan/prioritas penerapan sistem berdasarkan arsitektur aplikasi yang telah disusun sebelumnya sehingga dapat dilihat bahwa enterprise architecture yang akan diimplementasikan adalah penerapan berdasarkan urutan arsitektur aplikasi yang telah dihasilkan dengan terlebih dahulu mengimplementasikan inisiasi perencanaan, model bisnis, katalog sumber daya informasi yang ada dan arsitektur data.

Urutan rencana implementasi juga dilakukan dengan mempertimbangkan pengelompokkan aplikasi berdasarkan fungsi bisnis. Untuk arsitektur teknologi, karena yang dilakukan adalah mendefinisikan kebutuhan teknologi utama untuk mendukung aplikasi dan data, dan bukan merupakan analisis kebutuhan rinci, maka penerapannya masih harus dilihat berdasarkan kondisi real yang ada nantinya. Namun setidaknya arsitektur teknologi yang telah didefinisikan dapat memberikan gambaran umum kebutuhan teknologi yang harus disediakan untuk mendukung aplikasi dan data.

\subsection{Urutan Implementasi Aplikasi}

Hubungan antara aplikasi dan entitas data yang disajikan pada matriks relasi aplikasi dan entitas, merupakan suatu hasil dari arsitektur aplikasi yang mempunyai manfaat antara lain :

1.Memperlihatkan kondisi data sharing dalam arsitektur aplikasi

2.Dapat digunakan untuk membuat urutan aplikasi yang akan dibangun dengan prinsip aplikasi yang menciptakan atau membentuk (create) data sebaiknya diterapkan sebelum aplikasi yang menggunakan atau memakai (use).

Prinsip ini penting untuk menentukan kriteria urutan prioritas aplikasi yang akan dikembangkan sesuai dengan arsitektur yang telah dibuat. Dengan prinsip tersebut, maka penerapan implementasi aplikasi sebagaimana disarankan dalam EAP dapat dilakukan. Penerapan implementasi dijelaskan pada tabel 5 .

Tabel 5. Implementasi Aplikasi

\begin{tabular}{|c|c|c|}
\hline No. & Aplikasi & Keterangan \\
\hline I & \multicolumn{2}{|c|}{ Sistem Informasi Penerimaan Laporan Polisi } \\
\hline 1. & Pengelolaan Agenda Masuk & Pengembangan Ban \\
\hline 2. & Pengelolaan Laporan Polisi & Pengembangan Ban \\
\hline 3. & Pengelolaan Register & Pengembangan Ban \\
\hline 4. & Pengelolaan Laporan Perkembangan & Pengembangan Ban \\
\hline II. & \multicolumn{2}{|l|}{ Sistem Informasi Penyelidikan } \\
\hline 1. & Pengelolaan Hasil TKP & Pengembangan Ban \\
\hline 2. & Pengelolaan Hasil Pengamatan & Pengembangan Ban \\
\hline 3. & Pengelolaan Hasil Wawancara & Pengembangan Ban \\
\hline 4. & Pengelolaan Dokumen & Pengembangan Bar \\
\hline III. & \multicolumn{2}{|l|}{ Sistem Informasi Penyidikan } \\
\hline 1. & Pengelolaan Hasil Penyelidikan & Pengembangan Ban \\
\hline 2. & Pengelolaan SPDP & Pengembangan Ban \\
\hline 3. & Pengelolaan Berkas Perkara & Pengembangan Ban \\
\hline
\end{tabular}

\section{Kesimpulan dan Saran}

\subsection{Kesimpulan}

Berdasarkan tahapan yang telah dilakukan pada bab sebelumnya, maka dapat diambil kesimpulan sebagai berikut :

1. Berhasil membuat blueprint (data, aplikasi dan teknologi) yang merupakan landasan perbaikan dan pengembangan sistem informasi di Direktorat Reserse Kriminal Umum Polda Lampung dalam meningkatkan kualitas layanan kepada masyarakat.

2. Pembuatan blueprint (data, aplikasi dan teknologi) arsitektur enterprise untuk sistem informasi memberikan dokumentasi dan rujukan dengan rekapitulasi, diantaranya :

a. Model bisnis fungsional yang terdiri dari 6 (enam) area fungsi (3 buah area fungsi utama dan 3 pendukung) dan 25 (dua puluh lima) proses bisnis untuk total keseluruhan 9 unit organisasi yang terletak pada satu lokasi bisnis (satu gedung).

b. Katalog sumber daya informasi terdiri dari 3 (tiga) aplikasi legacy dengan landasan teknologi.

c. Arsitektur data terdiri 3 (tiga) buah entitas data dan 11 (sebelas) buah entitas data yang didefinisikan sebagai hasil identifikasi dengan dokumentasi : daftar entitas data dan subyek basis data serta matriks pemetaan fungsi bisnis dengan entitas data.

a. Arsitektur aplikasi, yang terdiri dari 3 kelompok aplikasi dengan 11 aplikasi.

b. Arsitektur teknologi, yang terdiri dari 22 prinsip teknologi, konfigurasi teknologi serta arsitektur bisnis dan distribusi landasan teknologi dengan aplikasi dan fungsi bisnis. 


\subsection{Saran}

Pada Penelitian ini yang dibangun atau dikembangkan hanya gambaran arsitektur informasi (blueprint) saja dan hanya mendefinisikan kebutuhan bisnis bukan merancang arsitektur bisnis. Maka dari itu perlu pengembangan selanjutnya.

\section{DAFTAR PUSTAKA}

[1] Afrizal, Y. (2013). Perencanaan Arsitektur Enterprise Sistem Informasi Pada Kantor Otoritas Pelabuhan Penyeberangan ( Kopp ) Ditjen Perhubungan Darat. Jurnal Ilmiah Foristek, Volume. 3(1), 260-268.

[2] Khairina, D., Mustafid, M., \& Noranita, B. (2012). Enterprise Architecture Planning untuk Pengembangan Sistem Informasi Perguruan Tinggi. Retrieved from http://eprints.undip.ac.id/35997/

[3] Kristanto, A. (2008). Perancangan Sistem Informasi. Yogyakarta: Gaya Media.
[4] Mentang, A. (2011). Pemodelan Arsitektur Enterprise Menggunakan Enterprise Architecture Planning Untuk Pelayanan Kepada Pelanggan Di PT. Indosat Tbk Sales Area Kendari.

[5] Spewak, S. H. (1992). Enterprise Architecture Planning (Developing a Blueprint for Data, Application and Technology). John Wiley \& Sons.

[6] Sutabri, T. (2003). Sistem Informasi Manajemen. Yogyakarta: Andi Offset.

[7] Tahriludin, U. (2012). Perancangan Enterprise Arsitektur Sistem Informasi Penjadwalan Menggunakan Kerangka Kerja TOGAF ADM (Studi Kasus: SMK Muhammadiyah 2 Kuningan).

[8] Utomo, A. P. (2014). Pemodelan Arsitektur Enterprise Sistem Informasi Akademik Pada Perguruan Tinggi Menggunakan Enterprise Architecture Planning. Jurnal SIMETRIS, 5(1), 33-40. https://doi.org/10.24176/simet.v5i1.129 
Redaksi :

Pusat Studi Teknologi Informasi (PSTI). Gedung Business Center Lt 2 J. Zainal Abidin No. 26 Bandar Lampung Telp. 0721 - 774626 g 772088555000

SistemInformasi@ubl.ac.id 